\title{
The Silk Road on Ice: China's Dream for an Arctic Belt and Road Route
}

\author{
Patrice Flynn, PhD \\ Professor of Business and Economics \\ Bolte School of Business \\ Mount St. Mary's University \\ 16300 Old Emmitsburg Rd, Emmitsburg, MD 21727 \\ United States
}

\begin{abstract}
The Anthropocene Era has resulted in shrinking ice shelves in the Arctic, opening up possibilities for significant growth in maritime infrastructure, hydrocarbon extraction, and military industries. The receding ice could create a shipping bonanza, trimming weeks off transit times and cutting fuel costs for vessels traveling between the Pacific and Atlantic Oceans. The Chinese see this as an opportunity to add a third route to their expansive Belt and Road Initiative, a Silk Road on Ice, described in this paper with an emphasis on the Sino-Russian alliance to make China's Arctic dream a reality.
\end{abstract}

Key words: Silk Road on Ice, China's Belt and Road Initiative, Polar Silk Road, Arctic Maritime Route, Sino-Russian Alliance

China's Belt and Road Initiative is one of the most expansive commercial endeavors today, connecting China with the far corners of the eastern hemisphere and beyond. Since China's 2013 unveiling of its vision to rejuvenate the ancient Silk Road, 136 nations have signed on as partners, Russian being the latest (PRC, 2019). New and upgraded infrastructure projects will link China with Indochina, South and Central Asia, Russia, the Middle East, Europe, Africa, South America, and Oceania. Beijing has committed the equivalent of one trillion dollars, with investments from participating nations possibly reaching eight trillion dollars. The Chinese Communist Party's strategic plan for the Belt and Road extends to 2049, to mark 100 years after Mao Zedong came into power and renamed the country, the People's Republic of China. The potential impact of the Belt and Road is mind-boggling.

The three aims of this ambitious transnational effort - economic growth, empire expansion, and regional stabilityreflect the vision of President Xi Jinping, who assumed the presidency in 2013, after serving as Secretary General of the Chinese Communist Party and member of the Politburo (PRC, 2015). On September 7, 2013 in Astana, Kazakhstan, President Xi announced the official launch of China's Silk Road Economic Belt, a land route traversing China, Central Asia, the Middle East, and Europe. The following month, in Jakarta, Indonesia, Xi announced China's intention to build a 21st Century Maritime Silk Road, seamlessly linking the South China Sea with the Bay of Bengal, Indian Ocean, Persian Gulf, Red Sea, Mediterranean Sea, and Atlantic Ocean.

The initiative has been met with both acclaim and criticism. Some nations praise the sophisticated new rail lines, airports, deep seaports, dry docks, auto expressways, special economic zones, and expansive economic corridors that in six years have significantly altered global trade routes and supply chains across the globe to China's advantage. Critics wonder how partnering nations will be able to repay the Chinese for loans incurred to build new infrastructure systems. Will inability to pay result in debt-for-equity swaps that leave China owning major pieces of the toll-based infrastructure it builds along the new Silk Road? What will the globe look like if China succeeds in connecting Northeastern, Eastern, and Southeastern Asia with the Middle East, Africa and Europe? History will be the judge.

\section{The Proposed Silk Road on Ice}

China has now set its sights even higher. In 2017, China proposed creating a third Belt and Road route, dubbed variously as the Silk Road on Ice, Polar Silk Road, and Arctic Silk Road. This route may soon traverse the Northern Sea Route, along the northern coastline of Russia to Scandinavia, potentially opening up a vast transportation network.

Historically, the Northern Sea Route was passable for transit shipping between the months of July and October, beyond which time the thickening ice and dense fog prohibited secure navigation. Facing this brief shipping window, mercantilists found fortune in commercial trade between the Pacific and Atlantic Oceans along southern maritime routes, navigable year-round. Such a calculus is about to change. 
China has its eyes set on the melting Arctic ice cap around the North Pole. The human-induced Anthropocene Era has resulted in shrinking ice shelves in the Arctic Ocean, opening up possibilities for significant growth in maritime infrastructure, hydrocarbon extraction, and military industries.

The receding ice could create a bonanza in destination shipping (e.g., resource extraction) and transit shipping (e.g., cargo) in the Arctic, trimming weeks off transit times for vessels traveling between ports in Asia and Europe. Who better to assist China open up the Arctic to commerce than its northern neighbor, the Russian Federation?

Throughout the 20th century, Russia proved its acumen navigating harsh northern environments. Russia's 13 robust icebreakers adroitly navigate the polar ice cap, eight of which are nuclear-powered and, hence, able to withstand winters snow-bound in Arctic waters. To date, Russia is the only country that operates nuclear icebreakers. China is following suit with China General Nuclear Power Group (CGN) planning to build a 30,000-ton nuclear icebreaker that will rival Russia's largest nuclear icebreaker (Zhen, 2019).

To further advance its maritime capabilities, Russia debuted its first floating nuclear power plant in 2019 on the Akademic Lomonosov barge, moored off the town of Pevek on the northern shore of Russia's Far East region. The barge's two nuclear reactors are capable of producing year-round electricity for the area's power grid. One of the advantages of a floating nuclear power plant, especially in the Arctic, is that "it does not have to be continually resupplied from great distances, often via frozen sea lanes, with bulky and spillable fossil fuel" (Economist, 2018:136). China has plans to produce 20 of its own nuclear barges that will power China's artificial islands in the South China Sea, built to protect Sino shipping routes. According to the Asia Times, "China's first fully-functional floating nuclear reactor should be seaworthy by 2021" (Robitzski, 2019).

With Russia's know-how navigating the Arctic and its fleet of nuclear icebreakers and floating nuclear power plants, China is learning a great deal from its northern neighbor and envisions a potentially lucrative collaboration on the proposed Silk Road on Ice.

\section{Russia's Decision to Partner with China}

Despite underlying tensions between Russia and China, President Putin extended a warm welcome to President Xi at the 2019 St. Petersburg Economic Forum, during which Russia became an official partner on China's Belt and Road Initiative, including the proposed Silk Road on Ice. On June 5, 2019, President Putin said to President Xi, "In recent years, thanks to your direct participation, the relationship between Russia and China has reached an unprecedently high level," to which President Xi responded, "Russia is the country that I have visited the most times, and President Putin is my best friend and colleague" (Economist, 2019b:93). Such staging mirrors the unending friendship between Joseph Stalin and Mao Zedong, dating back to 1949, at which time Mao was the junior partner (Desheng and Ren, 2019). Today, Putin is the junior partner, with China's GDP six times larger than Russia's. China is, however, dependent upon Russia for the majority of its oil as of 2019, because of waning oil imports from Saudi Arabia.

Heightened strains with the United States have played a hand in facilitating a Sino-Russian alliance surrounding the Silk Road on Ice. These two authoritarian governments have found a common foe in the U.S., albeit for different reasons. Russia finds itself shut out of the trans-Atlantic alliance because of its 2014 actions in the Ukraine and interference in the 2016 U.S. presidential election. China is shut out through rising tariffs imposed by the U.S. since 2018. As a result, China and Russia have found a way to do business that is of mutual value.

During Soviet times, the Northern Sea Route was off-limits to international entities until the Secretary General of the Soviet Communist Party, Mikhail Gorbachev, declared the Arctic Ocean an international entity in 1987. Thirty years later, the Russian Federation is actively inviting the People's Republic of China to partner with them to expand nautical activity along the shortest sea lane between Asia and Europe.

\section{Convergence of the Silk Road on Ice and the Northern Sea Route}

The Silk Road on Ice is a significant addition to China's dream for the Eastern Hemisphere. The route is envisioned to run from Dalian in eastern China, north to Vladivostok in Russia, past the coast of Alaska in the Bering Sea, along the northern coast of Russia, and ultimately to the Atlantic Ocean. The Chinese announced on June 20, 2017, that this proposed route will be part of its Belt and Road Initiative and secured confirmation from Russia on its partnership two years later, on June 5, 2019.

The proposed Silk Road on Ice is a 10,500 nautical-mile journey from China to Europe that takes about 35 days, significantly shorter than the 48-day average journey along the southern maritime route from the South China Sea, through the Suez Canal into Europe. The Northern Sea Route passage crosses several seas in the Arctic Ocean (i.e., 
Kara, Laptev, Eastern Siberia and Chukchi Seas) and the Bering Sea of the Pacific Ocean. Two other Arctic transit routes under consideration are the Transpolar Sea Route across the North Pole and a Northwest Passage along the Alaskan and Canadian coastlines.

\section{Climate Chaos}

At present, large transit ships avoid traveling along the Arctic Ocean because of the attendant dangers even during summer months. However, with climate change a reality and Arctic ice melting at historic rates, China sees an opportunity.

Arctic temperatures are warming twice as fast as the global average. Between 1980 and 2018, the Arctic sea ice coverage shrank from 7.9 million square kilometers total at its winter maximum, to 4.6 million square kilometers at its summer minimum. Russia has recorded more frequent unstable weather patterns in its northern regions, as a result. Severe weather phenomena, which the Russian weather service defines as intense weather events "from heatwaves to heavy winds that threaten human safety and can cause significant economic damage - rose from 141 to 580 in the past 18 years" (Economist, 2019c: 57-58).

One of the direct consequences of warming is that as white sea ice melts, deep blue waters appear. Because water absorbs more solar energy than white ice, melting is compounding in the region. Moreover, bunker-burning ships emit relatively high levels of sulfur-dioxide ( $\mathrm{SOx}$ ), leaving black ice in its wake, further intensifying temperature increases and ice melts. Large ice sheets break into smaller floating ice blocks, endangering maritime vessels.

Another consequence of climate change is rising temperatures in the Arctic's permafrost regions, which are rich in organic matter. When permafrost regions melt, they release a tremendous amount of carbon dioxide and methane into the air because organic matter in permafrost soil contains $20-50 \%$ carbon, relative to $5 \%$ carbon in normal garden soil (Economist, 2019b:93). These gases thaw the permafrost further, exacerbating the greenhouse effect.

As the Arctic natural infrastructure crumbles, skeletal remains of ancient plants and mammoth animals have been uncovered in northeastern Siberia due to (i) temperature rising, (ii) frozen land masses melting, and (iii) exposed permafrost soil. To host human habitat, "scientists say the planet's warming must not exceed $1.5^{\circ}$ Celsius $\left(2.7^{\circ}\right.$ Fahrenheit), but Siberia's temperatures have already spiked by more than $3^{\circ} \mathrm{C}\left(5.4^{\circ} \mathrm{F}\right)$ since preindustrial times, roughly triple the global average" (Troianovski and Mooney, 2019:A1).

Time-lapse NASA satellites show how the sea ice that swirls clockwise around the North Pole spreads during the winter and shrinks in the summer, leading NASA scientists to project ice-free summers by 2070, possibly as early as 2050, or even 2030 (NASA, 2017).

\section{Sino-Russian Alliance}

China is taking advantage of this significant climate phenomenon by adding an Arctic route to the Belt and Road Initiative to potentially increase shipping through the Arctic, saving energy and shipping time for container vessels and fossil-fuel tankers. For China to be successful with its Silk Road on Ice project, collaboration with Russia is advantageous.

Opening up the Arctic, however, invites commercial and geopolitical disputes. Russian Defense Minister Sergie Shoigu warned, "The Arctic has turned into an object of territorial, resource, and military-strategic interest for a number of states. This could lead to growth in potential conflict in the region" (Putz, 2018). Russia is paying close attention to President Xi's desire to create a Polar Silk Road because ships that traverse the Arctic route travel closely along Russia's northern coastline, the Northern Sea Route (NSR). The sea coast off northern Siberia is relatively shallow and free of ice for longer periods of time each year relative to other areas of the Arctic. For this reason, it is expected that Chinese transit vessels will most likely seek passage through Russian waters.

This requires securing a permit from Russia to enter the NSR and agreeing to pay pilotage and icebreaker fees. Port terminals book destination ships hour-by-hour for refueling, resupplying, maintenance, loading and unloading cargo, and emergency stops. Russia's Regional Governor for the Arkhangelsk region along the northwest Arctic coastline reports that the region will be fully operationalized and ready to receive transit and destination ships by 2025 (Emerging Market Investors Association, 2017). While ambitions abound, a sea trial of the first large container shipthe ice-clad Venta Maersk - attempted to cross the Northern Sea Route in record time. The vessel departed Vladivostok, Russia on August 22, 2018, and arrived in St. Petersburg, Russia on September 28, 2018. The 10,500 nautical mile journey took 37 days, exceeding the anticipated 23-day voyage. On-board Russian pilots and Russian nuclear-powered ice breakers assisted the vessel's safe passage, but not nearly in the time anticipated. PalleLaursen, 
Chief Technology Officer at the Danish shipping giant Maersk, reported afterward, "Currently, we do not see the Northern Sea Route as a viable commercial alternative to existing east-west routes" (Maersk, 2018). Nonetheless, at the 5th International Arctic Forum in St. Petersburg in 2019, the Russian government pledged 735 billion rubles $(\$ 11.5$ billion) towards the development of the Northern Sea Route between 2019 and 2025. Russia's Rosatom, the world's largest nuclear-powered ice-breaking fleet, promotes the initiative by telling its followers that the Northern Sea Route has "no queues and no pirates," unlike the Gulf of Aden (Putz, 2018). The Russians are also in discussions with the Chinese about a possible 2.5 billion-ruble ( $\$ 39$ million) port project in Tiksi, located in Yakutsk, where a new Russian military based has been built. Meanwhile, China's state-owned shipping giant COSCO will continue conducting experimental transits across the Northern Sea Route, carrying general cargo between China and Finland (Humpert, 2019).

Despite human-induced unstable weather patterns that are driving global protests in support of decarbonization and heightened attention to the 2019 UN Climate Action Summit, China and Russia are focusing on the upside. President Putin has described climate change as "a factor that bolsters optimism [and] provides more favorable conditions for economic activity in the region" (Economist, 2019c:57). Indeed, the melting of the Arctic could be quite lucrative for not only Chinese shippers but also Russian merchants.

\section{Maritime Cooperation under the Belt and Road Initiative}

On June 20, 2017, China's National Development and Research Commission and the State Oceanic Administration issued a plan to build three ocean-based blue economic passages as part of its 21st Century Maritime Silk Road (PRC, 2017). The first passage is the China-Indian Ocean-Africa-Mediterranean Sea passage, to connect the South China Sea to the Indian Ocean and onto Africa and Europe. The second passage is the China-Oceanic-South Pacific passage, from the South China Sea into the Pacific Ocean to Japan, Korea, and the west coast of the Americas. The third passage heads north from China to Vladivostok, Russia, through the Bering Straits, along the Arctic seas to Europe.

The third blue economic passage will provide access to Russian oil and gas fields; railway connections; tax-free ports; modern port handling services; warehousing facilities; and access to exported resources such as automobiles, lumber, pulp, coal, machinery, industrial products, consumer products, and other processed goods. Investors and shippers are particularly focused on the Russian ports of Arkhangelsk, Murmansk, and Vladivostok. If China is successful in negotiating a Free Trade Agreement with the Eurasian Economic Union (EAEU), trade between China, Russia, and other EAEU members is expected to expand.

The liquified natural gas industry (LNG) is actively negotiating expanded Arctic shipping routes along the proposed Silk Road on Ice. The LNG industry was well-represented at the 2nd Annual Belt and Road Initiative meeting in Beijing in April of 2019. China's two main LNG suppliers are the China National Oil and Gas Exploration and Development Company (CNODC) - a wholly owned subsidiary of China National Petroleum Corporation-and the China National Offshore Oil Corporation (CNOOC), both state-owned enterprises.

In 2019, the China National Petroleum Corporation (CNPC) and the China National Offshore Oil Corporation (CNOOC) purchased shares in Novatek's Arctic LNG 2 and Yamal LNG projects, in addition to forming the Maritime Arctic Transport LLC with Novatek to ship hydrocarbons on the Northern Sea Route. "Chinese companies are partowners and operate nine out of 15 Arc7 LNG carriers. This makes China by far the largest foreign operator of vessels along Russia's NSR," reports Arctic expert, Malte Humpert (2019).

Within a year, the investment started paying off. The commercial tanker, the Christophe de Margerie, loaded with LNG from the Yamal project, was the earliest tanker able to cross the eastern section of the Northern Sea Route without icebreaker assistance because of the extraordinary heat wave in northern Russia during the summer of 2020. The tanker departed Sabetta, Russia (the main seaport for the Yamal LNG project) on May 19, 2020 and arrived in Jingtang, China on June 10, 2020, a 23-day voyage, compared to 36 days through the Suez Canal.

Also in China's favor is a new Arctic law passed by the Russian Duma on March 11, 2020, that reduces to zero the severance tax rate on producing and processing hydrocarbon deposits in the East Arctic during the first 12 years of operations (Staalesen, 2020). The policy, which may be extended to LNG production, will encourage further SinoRussian polar ambitions to include Rosatom (state nuclear company), Rosneft (state oil company), Gazprom Neft (natural gas monopoly's oil extraction division), Vostok Coal, and Norilsk Nickel (mineral extractor). Part of the anticipated Northern Sea Route development are new railway lines, one to Sabetta and another between Arkhangelsk on the Arctic coast to Syktyvkar and Perm in central Siberia. 
In sum, China is actively vying for access to the Arctic. In 2013, the year President Xi announced the launch of the Belt and Road Initiative, China obtained observer status on the Arctic Council, which is comprised of eight member states (i.e., United States, Canada, Kingdom of Denmark, Finland, Iceland, Norway, Russia, and Sweden). The livelihoods, environment, and long-term well-being of the residents in the Artic region are thus intertwined with China's dream to add a Silk Road on Ice route to its ever-expanding Belt and Road Initiative.

\section{From the Arctic to the Antarctic}

The anticipated opening of the northern passage of the Silk Road on Ice by 2025 will significantly alter shipping, warehousing, mining, and logistics industries from Europe to Asia. But China's polar dream is not confined to the North Pole. The PRC is also heading to the South Pole with its announcement at the end of 2019 of China's two icebreakers (dubbed Snow Dragon and Snow Dragon 2) traveling to Antarctica where China has maintained a research base since the 1980s. Snow Dragon (Xue Long) was built in 1993; Snow Dragon 2 (Xue Long 2) was made in China in 2018. The latter established the PRC as a contender to become a "polar great power," according to President Xi Jinping.

New evidence suggests that China's Silk Road on Ice — coupled with its Digital Silk Road —will defy U.S. global dominance in physical infrastructure, finance, transportation, security, and telecommunications not only across planet Earth but also into the polar and equatorial orbits. This is a daunting thought for polar experts, merchants, and politicians the world over who carefully watch China's amalgam of soft, sharp, and hard power, which is reshaping the world in its own image.

\section{References}

Desheng, C. and Q. Ren. June 20, 2019. "President Xi Jinping's State Visit to Russia Signals Closer Relations.” China Daily.

Emerging Market Investors Association. July 11, 2017. "China's Maritime Arctic Silk Road on Ice." http://www.emia.org/news/story/5099.

Humpert, M. June 3, 2020. "Russia is one step closer to achieving year-round navigation in the Arctic. An ice-capable tanker made the earliest delivery of LNG to China via the Northern Sea Route." High North News. https://www.highnorthnews.com/en/arctic-ice-melts-russia-conducts-record-breaking-delivery-lng-china

Humpert, M. June 13, 2019. "Chinese Shipping Company COSCO to Send Record Number of Ships through Arctic." High North News. Bodø, Norway: Nord University. https://www.highnorthnews.com/en/chinese-shippingcompany-cosco-send-record-number-ships-through-arctic.

Maersk. September 28, 2018. "Maersk concludes trial passage of Northern Sea Route." Press Release.

NASA. March 11, 2017. "Sea Ice Extent Sinks to Record Lows at Both Poles. https://www.nasa.gov/feature/goddard/2017/sea-ice-extent-sinks-to-record-lows-at-both-poles.

People's Republic of China. Permanent Mission of the People's Republic of China to the United Nations. 2019. "The Belt and Road Initiative: Progress, Contributions and Prospects." Geneva, Switzerland: United Nations. https://www.china-un.ch/eng/zywjyjh/t1675564.htm.

People's Republic of China. The State Council Information Office. January 29, 2018. "China's Arctic Policy." https://eng.yidaiyilu.gov.cn/zchj/qwfb/46076.htm.

Peoples Republic of China. The State Council Information Office. January 2018. "China's Arctic Policy.” First Edition 2018.

People's Republic of China. National Development and Reform Commission. June 20, 2017. "Vision for Maritime Cooperation under the Belt and Road Initiative." http://www.xinhuanet.com/english/2017-06/20/c_136380414.htm. 9

People's Republic of China. National Development and Reform Commission. March 28, 2015. "Vision and Actions on Jointly Building Silk Road Economic Belt and 21st Century Maritime Silk Road." http://en.ndrc.gov.cn/newsrelease/201503/t20150330_669367.html.

Pincus, R. March 21, 2019. China and Russia in the Arctic. Testimony before the U.S. China Economic and Security Review Commission. pp. 189-215.

Pomerance, R. September 6, 2019. "Reflections on Fighting Climate Change.” DACOR Program. Washington, DC: DACOR Bacon Foundation.

Putz, C. November 9, 2018. "Can Russia and China 'Synergize' the Eurasian Economic Union and the Belt and Road Initiative?" The Diplomat.

Robitzski, D. March 21, 2019. “China Is Building up to 20 Floating Nuclear Power Plants.” Futurism. https://futurism.com/china-floating-nuclear-power-plant. 
Russian Federation. April 9-10, 2019. Arctic: Territory of Dialogue. 5th International Arctic Forum. St. Petersburg, Russia. https://forumarctica.ru/en/the-forum/results/

Staalesen, A. August 28, 2020. "There is no ice left on Northern Sea Route: but the number of ships that set course for the Arctic route still remains low." The Barents Observer.

https://thebarentsobserver.com/en/arctic/2019/08/there-no-ice-left-russias-northern-sea-route.

Sørensen, C.T.N. 2019. "Intensifying U.S.-China Security Dilemma Dynamics Play Out in the Arctic: Implications for China's Arctic Strategy." Arctic Yearbook 2019. Tromsø, Norway: Arctic Economic Council. https://arcticyearbook.com/arctic-yearbook/2019.

The Economist. November 30, 2019a. "Exploring the Antarctic: Heading South," p. 62.

The Economist. September 21, 2019b. "Ice Would Suffice," p. 93.

The Economist. September 21, 2019c. "Climate Change: A Warmer Russia," pp. 57-58.

The Economist. December 2018. "Power Play." The World in 2019, p. 136.

Troianovski, A. and C. Mooney. October 7, 2019. "In Siberia, a Mammoth Thaw." The Washington Post, pp. A1, A12A13.

Xi, J. October 18-24, 2017. "Xi Jinping Thought on Socialism with Chinese Characteristics for a New Era." Beijing, China: 19th National Congress of the Communist Party in China.

Zhen, L. March 20, 2019. "Could China's 'Experimental' Ship be the World's Biggest Nuclear-Powered Icebreaker?" South Morning China Post. https://www.scmp.com/news/china/military/article/3002455/china-build-30000tonne-nuclear-powered-ship-described. 